\title{
High and steady or low and rising? : life-cycle earnings patterns in vocational and general education
}

Citation for published version (APA):

Cörvers, F., Heijke, J. A. M., Kriechel, B., \& Pfeifer, H. (2011). High and steady or low and rising? : lifecycle earnings patterns in vocational and general education. Researchcentrum voor Onderwijs en Arbeidsmarkt, Faculteit der Economische Wetenschappen. ROA Research Memoranda No. 7 https://doi.org/10.26481/umaror.2011007

Document status and date:

Published: 01/01/2011

DOI:

10.26481/umaror.2011007

Document Version:

Publisher's PDF, also known as Version of record

\section{Please check the document version of this publication:}

- A submitted manuscript is the version of the article upon submission and before peer-review. There can be important differences between the submitted version and the official published version of record. People interested in the research are advised to contact the author for the final version of the publication, or visit the DOI to the publisher's website.

- The final author version and the galley proof are versions of the publication after peer review.

- The final published version features the final layout of the paper including the volume, issue and page numbers.

Link to publication

\footnotetext{
General rights rights.

- You may freely distribute the URL identifying the publication in the public portal. please follow below link for the End User Agreement:

www.umlib.nl/taverne-license

Take down policy

If you believe that this document breaches copyright please contact us at:

repository@maastrichtuniversity.nl

providing details and we will investigate your claim.
}

Copyright and moral rights for the publications made accessible in the public portal are retained by the authors and/or other copyright owners and it is a condition of accessing publications that users recognise and abide by the legal requirements associated with these

- Users may download and print one copy of any publication from the public portal for the purpose of private study or research.

- You may not further distribute the material or use it for any profit-making activity or commercial gain

If the publication is distributed under the terms of Article $25 \mathrm{fa}$ of the Dutch Copyright Act, indicated by the "Taverne" license above, 
1) Maastricht University

Research Centre for Education and the Labour Market | ROA

\title{
High and steady or low and rising? Life-cycle earnings patterns in vocational and general education
}

\author{
Frank Cörvers \\ Hans Heijke \\ Ben Kriechel \\ Harald Pfeifer
}

\section{ROA Research Memorandum}

\author{
ROA-RM-2011/7
}

Research Centre for Education and the Labour Market Maastricht University

P.O. Box 616,6200 MD Maastricht, The Netherlands

$\mathrm{T}+31433883647 \mathrm{~F}+31433884914$

secretary-roa-sbe@maastrichtuniversity.n www.roa.nl 


\title{
High and steady or low and rising? Life-cycle earnings patterns in vocational and general education
}

\author{
Frank Cörvers \\ Hans Heijke \\ Ben Kriechel \\ Harald Pfeifer
}

ROA-RM-2011/7*

August 2011

Research Centre for Education and the Labour Market

Maastricht University

P.O. Box 616, 6200 MD Maastricht, The Netherlands

$\mathrm{T}+31433883647 \mathrm{~F}+31433884914$

secretary-roa-sbe@maastrichtuniversity.nl

www.roa.nl

\footnotetext{
* The ROA Research Memorandum Series was created in order to make research results available for discussion, before those results are submitted for publication in journals.
} 


\section{Abstract}

\section{High and steady or low and rising? Life-cycle earnings patterns in vocational and general education ${ }^{* *}$}

In this paper, we compare experience-earnings profiles of employees with vocational and general education background in Germany, the Netherlands and the United Kingdom, three countries with fundamentally different education systems. Using Mixed-Effects Linear Regression Models we show that earnings of vocationally educated employees are higher in the initial phase of their career. However, those with a general education background catch up over time in the labor market. Life-cycle differences in earnings are more pronounced in Germany than in the United Kingdom and the Netherlands.

JEL Classification: J24, J31

Keywords: Education Systems, Human Capital, Earnings Profiles

Frank Cörvers

ROA

Maastricht University

P.O. Box 616

6200 MD Maastricht

The Netherlands

frank.corvers@maastrichtuniversity.nl

Ben Kriechel

ROA

Maastricht University

P.O. Box 616

6200 MD Maastricht

The Netherlands

and Institute for the Study of Labor (IZA)

b.kriechel@maastrichtuniversity.nl
Hans Heijke

Department of Economics and ROA

Maastricht University

P.O. Box 616

6200 MD Maastricht

The Netherlands

h.heijke@maastrichtuniversity.nl

Harald Pfeifer

Federal Institute for Vocational

Education and Training (BIBB)

Postfach 201264

53142 Bonn

Germany

harald.pfeifer@bibb.de

** The authors thank Derek Bosworth, Arnaud Dupuy, Bart Golsteyn, Marc van der Meer, the participants of the XIX Meeting of the Economics of Education Association 2010 in Zaragoza and the participants of the ESPE-Conference 2010 in Essen for their helpful comments. This research has been partly financed by the Centre for Expertise in Vocational Education and Training (ecbo), Utrecht/Den Bosch. 


\section{Introduction}

Countries differ with respect to their education systems determining the supply of human capital to firms in an economy. While initial vocational education is an important component of education systems in several industrialized countries, other countries focus mainly on the provision of general education. Among those countries with an elaborate vocational system, notable differences exist concerning the way skills are formed. While some countries focus predominantly on school-based vocational education, others feature a system of combined school- and work-based vocational education and training. The work-based component varies in those systems, and is highest for apprenticeship forms of vocational education and training (dual system), as found in Germany and, to a somewhat lesser extent, in the Netherlands. An example of a country with a mainly general education system is the United Kingdom. Although apprenticeships have a long history in that country, quantitatively they play a less important role.

The aim of the article is to analyze differences in earnings of individuals that have participated in different educational (i.e. a general or vocational) programs. One motivation for doing so is that the appropriateness of vocational systems of education in generating the skills needed in a modern economy has repeatedly been called into question. The structural change away from traditional crafts and industries toward services and, more broadly, the move to a knowledge-based economy is thought to require more systemic and theoretical knowledge and skills, which allow for more flexibility in rapidly changing labor markets (Bowman 1993, Baethge et al. 2006). It is argued that education systems providing general qualifications better meet the demand of firms operating in restructuring economies (Heidenreich 1998). Adding to that argument, figures published by the OECD (OECD 2008) show that in countries with elaborate vocational systems, expenditures for students in vocational education are much higher than for students in general education programs. While this is the case for Austria, Germany and Switzerland, costs for general programs exceed those of vocational programs in the Netherlands. The question has to be posed as to whether vocational educa- 
tion generates high costs without offering corresponding benefits, especially for economies undergoing rapid technological change.

Costs of educational programs, as published by the OECD, are relatively straightforward to measure. However, costs are only one part of the story. Before judging the efficiency and effectiveness of different educational pathways, the benefit side also needs to be considered thoroughly. The provision of upper-secondary education to those students who are more practically oriented and would not otherwise enter upper-secondary education at all is one example of such benefits (see for example Gangl 2002). The close tie to firms and labor markets, especially in dual systems, offers greater chances of employment in comparison to those available to persons without upper-secondary qualification.

The present paper focuses on earnings after having undergone upper- secondary vocational or general education. We compare experience-earnings profiles for employees from each educational track, under the hypothesis that initial earnings and the subsequent experience-earnings curves for the two groups will differ. The reason for this is that young adults opting for vocational programs, which often comprise work-experience, become "specialists" over the time they spend in the program. The match between acquired and required skills already improves during the educational phase, which is not the case for young adults following a more general education path. For the latter group, we expect that the lack of specialization and work experience will translate into lower initial productivity and thus lower initial earnings compared to vocationally educated employees. Following this logic, the greater the share of vocation-specific training in the program, the better the initial match and the higher initial earnings. On the other hand, general education delivers a broad body of general knowledge that is the foundation for efficient job adjustments over their careers and for responding rapidly to technological change (Goldin 2001). Thus, over time, generally educated employees also reach their "optimal" productivity level by learning "on the job", by participating in continuing vocational training activities, or by changing jobs and occupations. Since this broader foundation is likely to offer more opportunities to increase productivity later on in working life, one result of 
our analysis may well be that the wage curves of the vocationally and the generally educated intersect at some point over their working lives, and that the generally educated reach a higher earnings-level than their vocationally educated fellow employees.

In this paper, we concentrate on employees with qualifications at the uppersecondary level. Employees with either higher (i.e. tertiary) or lower level education are not included in the analysis. The reason for this focus lies in the fact that employees at this level form the largest part of the workforce in the three reference countries. This "middle qualification level" encompasses employees who are an important factor in driving production and growth in an economy. Estimates based on the European Labour Force Survey (EULFS) show that in Germany over 60 per cent of the workforce between 15 and 64 years of age has earned a qualification at upper-secondary level. In the Netherlands and the United Kingdom this share is somewhat lower (45 per cent), but still much higher than that of the respective groups at lower secondary or tertiary leve 1 .

The contribution of the paper to the literature is threefold. First, the paper offers interesting results on the impact of different types of upper-secondary level education programs (i.e. vocational and general) on life-cycle-earnings. Although a number of studies exist that estimate wage effects of vocational qualifications for Israel and the United States (Neuman and Ziderman 1991, 1999; Hotchkiss 1993; Meer 2007), evidence for European countries is rare. Second, by conducting the analysis for three different countries, we contribute to the ongoing debate on the benefits of vocational education and training systems in an international context, as put forward by e.g. Gang] (2000). Third, by employing an econometric model that to the best of our knowledge has so far not been used for estimating the impact of different educational programs on earnings, we also add to the methodological discussion in this area of research. Nevertheless, we cannot rule out that selection into vocational and general education might bias our results even when narrowing down the comparison groups. We do, however, offer a number of robustness checks and discuss the inclusion of a additional control variable

\footnotetext{
${ }^{1}$ The shares refer to the year 2007 . Source is the Eurostat data-base New Cronos.
} 
to deal with selection issues.

The estimation results show that, in accordance with our main hypothesis, vocationally educated have initially higher earnings compared to generally educated employees. The earnings difference is strongest in Germany and somewhat weaker but still significant in the United Kingdom. In these two countries, also the expected catching-up process takes place so that earnings profiles cross after about 8 years of labor market experience. In the period following, generally educated reach a higher level of earnings. This result, however, is not significant for the Netherlands, where neither earnings advantages of vocationally educated nor catching-up processes seem to be existent. However, part of this result might be due to sample size restrictions.

The remainder of the paper is structured as follows. After giving a short overview on theoretical aspects and on the literature in section 2, we in section 3 discuss education systems in the three countries of reference. In section 4, we describe the data sources chosen for the analysis. The estimation of age-earnings profiles is done in section 5 and 6 via simple OLS earnings-equations and mixed-effects linear regression models. The last section offers an overview on the main results and draws conclusions from the analysis.

\section{Literature and Theoretical Aspects}

The hypothesis of differences in life-cycle earnings patterns for vocational and general education touches upon several strands of literature. First, the relation between education and earnings is one of the most popular topics in economic literature since the seminal works of Becker (1964) and Mincer (1958, 1974). An overview of methods and applications estimating returns to education based on the ideas of Mincer can be found in Grossbard (2006). Second, literature about job-matching is relevant for the analysis presented in this paper, since we argue that the shape of experience-earnings profiles reveals information about the matching of individual skills and the job-requirements of firms. Concerning the latter, the importance of job 
characteristics for productivity and earnings has been stressed by Thurow (1975) in his job competition model. Bringing both supply and demand of skills together has been the aim of job-matching theory, which has been advanced by authors like Jovanovid (1979) and Hartog (1992).

Taking this literature as a starting point, van Eijs and Heijke (2000) develop a theoretical model in which earnings-tenure profiles are derived. Initial earnings give an indication of the quality of the match at the beginning of a job. In this framework, training "on-the-job" is used to decrease the mismatch between acquired and required skills, whereas the costs for training are mainly shifted to the employee who receives lower wages at the beginning of his career. Estimating earnings functions by occupational level and occupational field, they conclude for the Netherlands that academic graduates have a comparative advantage in complex jobs and those with a low educational level have a comparative advantage in low level jobs. The same is concluded for employees with a medium level of education, i.e. also for this group of employees there is evidence of a comparative advantage over differently qualified employees in the same type of (intermediate level) jobs. Building upon a contribution by Willis and Rosen (1979) and extending the methodological and thematic scope, Meer (2007) analyzes the effect of track choice (general vs. academic vs. technical vs. business) on earnings. Meer concludes that "the evidence points to comparative advantage in track selection: those on the technical track are best off there, and those on the academic track are best off following that path" (p.572). Thus, the supply of different tracks seem to be beneficial for differently "gifted" students. Pischke et al. (2007) analyze the returns to apprenticeship training in Austria. The authors find wage returns of about the same size as returns to other forms of education, such as school based education in colleges. Also Neuman and Ziderman (1991, 1999) and Hotchkiss (1993) estimate the effects of secondary vocational training on the wage received and find mixed results. While Neuman and Ziderman find a positive and significant impact on wages for Israel, Hotchkiss finds no significant effects for the US. An important point made by several authors is that individuals differ with respect to ability, social background and interest, and that these differences need 
to be taken into account when analyzing earnings of differently qualified employees.

Yet another strand of literature deals with institutional frameworks and their role in the matching processes in the labor market. Marsden and Rvan (1986) and Marsden and Ryan (1991) point out the importance of education systems for labor market integration of young adults. They broadly differentiate between two institutional arrangements, one with and one without strong apprenticeship systems. The resulting labor markets are either internal labor markets (ILM) or occupational labor markets (OLM). The key difference between the two is the presence of an education and training system providing occupationally-specific skills, thus transforming the stratification system from an internal labor market type into an occupational labor market system. Gangl (2000) points out that

"the structure of the education and training system is a key factor in determining the nature of the stratification system, resulting in two distinct institutional equilibria of particular types of training systems and thus in specific patterns of stratification. More specifically, it is the relative reliance of market matching processes on formal education versus experience and mobility, which is at stake here. In the context of vocationally specific and occupationally relevant initial training, the education and training system performs an effective presorting of individuals and allows for a stratification system based on certified skills. In the absence of such training systems, matching processes have to rely relatively more on experience and mobility, thus yielding a different type of stratification system" (p.3).

The cited literature points towards an important aspect that needs to be taken into account when analyzing age-earnings profiles: Education systems and labor markets are institutions that interact with each other. The way 
education is organized in a country influences the quantity and quality of skills offered on the labor market. Firms, in turn, adjust their organizational structure and business strategies to the amount and type of human capital "available" on the labor market. In our case, Germany and the Netherlands are examples of an occupational labor market (OLM) arrangement, while the United Kingdom can be classified as an internal labor market (ILM) arrangement. The general question that emerges is whether different systems result in different labor and product market outcomes. While works of the authors cited above and others focus mainly on the role of vocational education and training in the employment (unemployment) outcome and further labor market career of young adults, the task of this paper is to analyze earnings differences between differently qualified employees over the life cycle in different educational systems.

A central assumption is that earnings reflect upon the productivity of employees and that therefore experience-earnings profiles may be used to obtain an indication of the quality of the initial match between acquired and required skills and the development of productive capacities over the working life2. The quality of the initial match is related to the earnings received at the beginning of a labor market career. Along the dimension of labor market experience, earnings are assumed to increase due to on-the-job learning and continuing vocational training (Gustman and Steinmeier 1982; Mever 1982). Over time, however, the assumption is that the slope of the experienceearnings curve declines indicating that on-the-job training and especially formal training becomes less attractive the older and thus the closer to retirement employees are. Overall, we expect a concave experience-earnings

\footnotetext{
${ }^{2}$ The assumption that earnings reflect the productivity of employees is not unchallenged. Several authors (Acemoglu and Pischke 1998, 1999, Booth and Zoega 2004, Brunello 2002) claim, for example, that wage compression (i.e. the gap between productivity and wages that increases with the amount of human capital) is an important feature of many industrialized economies and explains the investment of firms in general human capital. Dearden et al. (2006) show that productivity increases induced by training exceed the wage gains for the training participants. However, for the analysis in this paper it is sufficient that productivity and earnings are monotonically positive related i.e. highly productive workers earn more than less productive workers.
} 
profile for both vocationally and generally educated employees.

Figure 1: Hypothetical Experience-Earnings Profiles

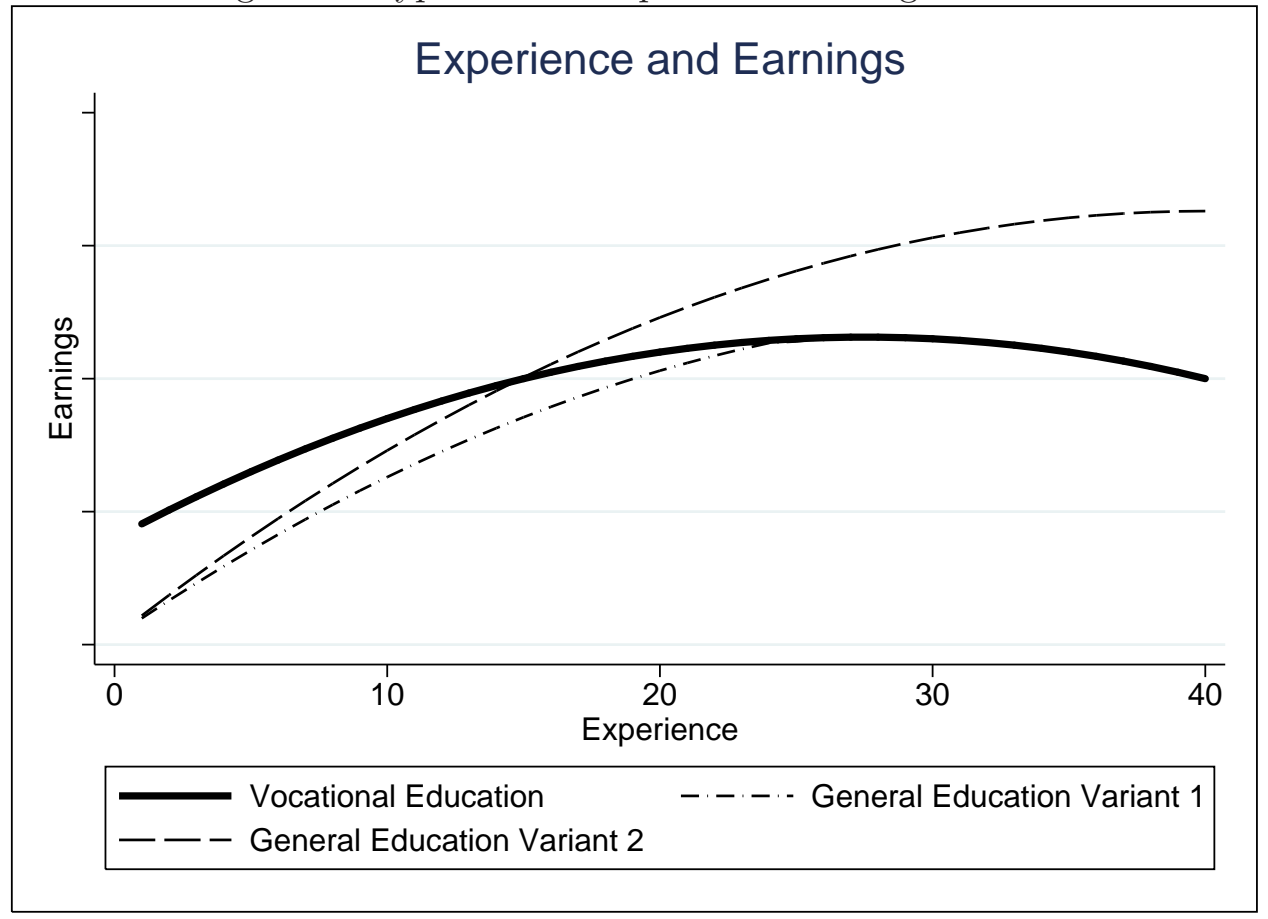

Differences in initial earnings and the shape of the experience-earnings curves can be interpreted in the following way: Higher initial earnings for one group of employees imply a comparative advantage over the other group of employees. Although both groups of employees have obtained an education at the same (upper-secondary) educational level and thus have "invested" the same amount of time in their education, the "track choice" has been different. Whether this advantage holds over time depends on the shape of the experience-earnings curves. The curve is assumed to rise more steeply the more productive an employee becomes. The increase in productivity (and thus in earnings) stems from the acquisition of additional human capital through on-the-job learning and continuing vocational training. According to our argument, we would expect higher initial earnings for vocationally 
trained employees and a catching-up process for generally educated thereafter, as shown in Figure 1. In the first scenario shown in the graph (Variant 1 ), the curve of the generally educated converges to the one of the vocationally educated. This means that generally educated reach the productivity level of vocationally educated after some time in the labor market e.g. by way of on-the-job training. The "final" level of productivity and wages are similar for the two groups. In the second scenario, the curve of the generally educated rises more steeply than in Variant 1 and intersects with that of the vocationally educated at some point over working life. A catchingup process takes place and at some point generally educated become more productive than vocationally educated (Variant 2). Whether either group has an advantage over the other depends on the point in time at which the two curves intersect. Assuming that the initial ability of both groups is controlled for, Variant 2 would contain an important message, namely that general education, ceteris paribus, leads to a higher productivity level than vocational education. The reason for this could be that the ability for learning throughout the working life differs between the two groups and that on-the-job training is more effective in the case of generally educated employees. This, on the other hand, would not mean that vocational education is inferior to general education from an individual perspective, since the initial earnings-advantage may still offset the gains obtained through a higher "final" productivity level. To understand how general and vocational education is organized in the three reference countries, the following section offers a short overview over the respective education systems.

\section{Education Systems}

\subsection{Germany}

Full-time education in Germany is compulsory between the ages of six and sixteen (or fifteen, depending on Land) and part-time education is compulsory until the age of eighteen for those, who do not attend a full-time school. Already by the age of ten, most students are channeled into three secondary school types with the Hauptschule lasting another five years, the 
Realschule six years and the Gymnasium eight to nine years of full time education. Regardless of the school-type attended, students have the option to start vocational education (either school-based or dual) after completion of either of the school-types or to continue at the respective "higher" schooltype (e.g. transition from Hauptschule to Realschule or from Realschule to Gymnasium). Only those who graduate from the Gymnasium gain access to university. Those who complete at least the twelfth year (out of usually thirteen) in the Gymnasium may enter the Fachhochschule (polytechnical university).

Concerning the organizational aspects of education, there is a clear distinction between general education, full-time vocational education in schools and the apprenticeship system. General schools and vocational schools are separate institutions with separate administration. Part-time vocational schools in apprenticeship training are, on the other hand, institutionally integrated with full-time vocational schools. Both are under the responsibility of the Länder. The contents and regulation of apprenticeship training within the firm is determined on the federal (central government) level.

More than two thirds of a cohort (2004) of school leavers finish school after lower secondary education (usually at the age of sixteen) with a general leaving certificate from the Hauptschule or with an advanced leaving certificate from the Realschule. The vast majority of these (around 65 percent of a cohort) starts a vocational training directly after leaving school. Most of them (around 50 per cent of a cohort) start an apprenticeship in the "Dual System" that combines training in a company with education in a part-time vocational school. About fifteen per cent of the cohort enters full-time vocational schools (Berufsfachschulen). The typical age of students beginning initial vocational education and training (IVET) either by starting an apprenticeship or a school-based vocational education is between sixteen and twenty years, whereas average entrance age has been increasing over the last two decades. 


\subsection{The Netherlands}

In the Netherlands, school attendance is compulsory until the age of sixteen. Between the ages of sixteen and eighteen, there is a partial compulsory education (partiële leerplicht), meaning a pupil must attend some form of education for at least two days a week. Access to the senior secondary vocational education MBO (middelbaar beroepsonderwijs) is granted for those who have completed at least the first phase of (general) secondary education. Three types of secondary education exist: Junior general and prevocational education (voorbereidend middelbaar beroepsonderwijs, VMBO)) with a duration of up to four years, senior general secondary education (hoger algemeen voortgezet onderwijs, HAVO) with a duration of five years and preuniversity education (voorbereidend wetenschappelijk onderwijs, VWO) with a duration of six years. All three types of secondary education begin their program with a period of basic secondary education (basisvorming) during which all students study a similar range of subjects (although possibly at different levels), whichever their type of school. The duration of this period varies from one type of school to another, but is at least two, usually three years. After completing VMBO at the age of sixteen, students can enter the vocational system of MBO. Students who have completed the theoretical program within VMBO with high average grades can alternatively enter senior general secondary education (HAVO). The most common access to the MBO, however, is via VMBO.

Two learning pathways exist within MBO: The block- (or day) release pathway BBL (beroepsbegeleidende leerweg) and the vocational schooling pathway BOL (beroepsopleidende leerweg). BBL is a learning pathway, which comprises at least 60 per cent training in a company, and the rest at a schoo 3 . Students sign a contract with the company where they receive workplace training. This learning agreement specifies that the student both works and learns within the company. The BBL is very much related to the German form of apprenticeship system. BOL, on the other hand, is a more theoretical pathway with a the share of practical occupational training

\footnotetext{
${ }^{3}$ In a number of BBL-programs, participants go to school only one day in a working week.
} 
between 20 and 60 per cent of the students' time. Generally, it is possible to attend any training in the qualification structure through both pathways. With respect to the relative importance of the vocational system in the Netherlands, close to 70 per cent of all students in upper-secondary education are enrolled in vocational programs, of which close to 20 per cent follow an apprenticeship program in the BBL (OECD 2008).

\subsection{United Kingdom}

Schooling in the United Kingdom is compulsory from age five to sixteen. All publicly funded schools must provide the National Curriculum. At the age of sixteen most students take public examinations, the General Certificate of Secondary Education (GCSE) (level 2) in England, Wales and Northern Ireland and the Standard Grade in Scotland. GCSEs are normally taken in a range of single subjects, and a certificate is issued listing the grade achieved in each subject. After completion of compulsory education in secondary schools, young people may choose to continue in school, move to a sixthform college or further education (FE) college, enter an apprenticeship or enter employment.

Students remaining in education at a school or a college may choose between general (academic) and vocational subjects or take a mixture of the two. Normally, the upper-secondary phase lasts two to three years, from age sixteen to eighteen or nineteen. The dominant qualification is General Certificate of Education (GCE) A-levels (level 3). A-levels are elective single subject qualifications, which students choose on the basis of GCSE qualifications, interest and intended destination. Students are encouraged to study up to five subjects in the first year of post-secondary education and upon completion; they are awarded the GCE Advanced Subsidiary (AS) qualification. Those who continue in the second year, study more demanding units in three of these five subjects in order to obtain the full GCE A-level on successful completion.

Vocational education may be undertaken at secondary school, or at an FE college, or with other training providers, whereas two forms of vocational education exist: First, school-based vocational education is undertaken either 
at school (for those aged up to eighteen) or at a FE college (for those aged sixteen and older). Successful completion could lead to direct employment or to further training, within a FE college or with another training provider. Second, programs of specific training are undertaken at a FE college and allow entry to a particular trade or profession (such as hairdressing, construction trades etc). This form of education is a blend of both initial and continuing vocational training.

Within the UK, there is no unified VET structure. Historically, VET has developed in an ad hoc way, rather than through central planning (CEDEFOP, 2008). Nonetheless, VET provision can be summarized according to the various contexts within which it takes place. With respect to the relative importance of vocational education and training in the United Kingdom the OECD reports about 40 per cent of students in upper-secondary education to be enrolled in a vocational education program. The share of those in programs combining school and work (like apprenticeships) is considered to be rather small, especially when compared to the Netherlands and Germany.

\subsection{Common Aspects}

To compare labor market outcomes in different countries, in this case the earnings of employees, it is useful to pin down the common features and main differences between education systems. The education systems of all three countries feature compulsory education at least until the age of sixteen. At this stage, students in the three countries have different options for continuing their educational career. One alternative, which is not unusual in the United Kingdom but less frequent in Germany or the Netherlands, is to leave the formal education system and enter the labor market. Those remaining in the formal education system have the choice between either more general education or vocational education with varying shares of company-based training. In Germany, this share is largest with students spending about two days of their week in vocational schools and three days at the workplace. The same holds for the BBL-programs in the Netherlands. The BOL-participants, however, have considerably lower shares of companybased training. In the United Kingdom, vocational programs generally con- 
tain lower shares of company-based training (except for apprenticeships). For students remaining in the general system, the aim is to gain an uppersecondary qualification that opens the way to tertiary education. Once achieved, however, students of the three countries (again) have the choice between continuing formal tertiary education or entering employment. In contrast, for the vast majority of those opting for a vocational path at the age of sixteen, the usual way is to enter the labor market after obtaining an upper-secondary vocational qualification.

In this paper, the focus is especially on employees who have obtained an upper-secondary qualification either by following a vocational or a general educational program. Employees who have obtained either no uppersecondary education at all, or who have gone on to obtain tertiary qualifications after finishing upper-secondary education, are excluded from our analysis.

\section{Data and Variable Construction}

The data source for Germany is the socio-economic panel (GSOEP). The GSOEP started in 1984 as a longitudinal survey of private households and persons in the Federal Republic of Germany. From 1990, an additional sample was launched covering the eastern part of Germany. The central aim of this panel study is to collect representative micro-data on persons, households and families, covering variables in education and training, labor market and occupational dynamics, and earnings. For our comparative approach, variables of earnings and education as well as personal-level and firm-level information have been extracted. For reason of a comparative reference period, the GSOEP data-set has been restricted to the years 1991 to 2006.

For the analysis in the Netherlands, the data used has been produced by the Institute of Labour Studies (OSA). OSA conducted a survey every two years to collect data about the (potential) labor force in the Netherlands. The first wave of the OSA Labour Supply Panel was carried out in 1985. Subsequent surveys have taken place every two years (from 1986 to 2006). 
The survey asks about respondents' employment situation and their behavior on the labor market. Further, information about education and earnings is gathered.

For the United Kingdom, the British Household Panel Survey (BHPS) is an appropriate data source for our analysis. Like its German and Dutch counterparts, the BHPS is a representative multi-purpose panel study. It started in 1991 and has been conducted since on a yearly basis. From this panel survey, rich information on the labor market situation, earnings and education and further personal and firm information can also be obtained. Similarly to the German panel, data from 1991 to 2006 is used for the estimation of earnings-profiles.

When using data from different countries, one needs to be cautious about constructing a common set of variables for comparative analysis. It must be ensured that variables mirror the same information across countries. This is especially true for variables reflecting specific national frameworks. One example is the variable used to distinguish between employees who have obtained either vocational or general qualifications. In the case of Germany and the Netherlands, the strict division of vocational and academic pathways inherent to the education systems simplifies the work. Here, a generated variable on the CASMIN classification offers an easy way to distinguish former students of each educational pathway (Brauns and Steinmann 1999). This is not so straightforward in the case of the United Kingdom. Both vocational and general qualifications may, for example, be obtained in $\mathrm{FE}$ colleges. The identification strategy was first to determine those employees with a highest educational attainment at the upper-secondary level, and then to use further information on the type of qualification obtained, i.e. whether it was vocational or general 4 . The earnings variable is the gross hourly real wage in Germany and the United Kingdom. For the Netherlands, hourly net-earnings are the only information available. For the estimation of earnings-profiles, we extracted several comparable variables, such as gender, age and firm-size, directly from the respective panel data sources. Concern-

\footnotetext{
${ }^{4}$ The variable is generated by ISER and has been derived using several other education variables and mirrors whether the respondent has obtained a vocational qualification.
} 
ing economic branch and occupation the international classifications NACE and ISCO were used for Germany and the United Kingdom. For the Netherlands, the respective national classifications based on NACE and ISCO were used.

Tables A.1 to A.3 in the appendix display the descriptive statistics for a number of relevant variables separately for generally and vocationally educated employee 5 . It is important to note that, especially in Germany, the group-size (and thus the number of observations) for employees with general education is relatively small. This reflects the fact that most of the students gaining upper-secondary qualifications either continue to university or at least follow a "high-quality" apprenticeship (e.g. bank clerk, technician or middle manager). Further, generally educated persons entering the labor market are, on average, much younger and consequently have much lower values for experience. This is different for the United Kingdom and the Netherlands. Here, the two reference groups are more homogeneous with regard to these characteristics. However, since age is controlled for in our regressions, this asymmetry should not affect our results. For the analysis, we pooled those waves of the panel data sources that were available at the time writing this paper. For the GSOEP, this comprises all waves from 1991 to 2006. For the OSA-panel, waves 2000 to 2006 were available. Prior waves do not directly allow for any differentiation between vocational and general qualifications. As in the case of the GSOEP, waves 1991 to 2006 were used for the BHPS.

As described above, we restrict our sample to employees who have obtained an upper-secondary qualification either through a vocational or a general type of educational program. Our assumption is that those two groups of employees are comparable with regard to unobservable characteristics responsible for selection into different tracks and labor market outcomes. One component of our strategy to control for selection is thus to narrow

\footnotetext{
${ }^{5}$ Although tenure is described in the table, it is not used in the regressions due to potential endogeneity problems. However, simulations including tenure and tenure interactions showed that the inclusion of these variables in the regression would not significantly alter the results.
} 
down the samples to persons having similar levels of ability or a similar social background. Those employees who have either not attained uppersecondary education or who have completed tertiary education are removed from the data-sets.

Further, we restricted the data to persons between 18 and 64 years of age. The lower age limit is chosen due to the fact that the age of 18 is the "earliest" age at which young adults can obtain an upper-secondary qualification. Further, by choosing a higher age limit we would lose information on initial wages, which is central for our reasoning. We drop those observations that have a missing value in the earnings or one of the control variables. In the pooled data-sets we are left with around 70,000 observations for Germany, around 2,500 observations for the Netherlands and nearly 40,000 observations for the United Kingdom. Whereas the sample size for Germany and the United Kingdom is relatively large, the low sample size for the Netherlands should be kept in mind when interpreting the subsequent estimation results.

\section{$5 \quad$ Estimating Earnings-Experience Profiles}

\subsection{Pooled OLS-Regression}

We first estimate a simple OLS model for each pooled data-set of the three countries. To do so, we regress log hourly wages on a set of explanatory variables. The equation then has the form

$$
\begin{aligned}
& y_{i}=\beta_{1}+\beta_{2} \operatorname{voc}_{i}+\beta_{3} \exp _{i}+\beta_{4} \exp _{i}^{2}+\beta_{5} v_{0} c_{i} * \exp _{i} \\
& +\beta_{6} v_{0} c_{i} * \exp _{i}^{2}+\beta_{7} X_{i}+\epsilon_{i}
\end{aligned}
$$

where $\mathrm{X}$ is a vector of further control variables. The estimation results of the baseline model with $\mathrm{X}$ containing merely the individual characteristic gender and time dummies are shown in Table A.4. For Germany, the coefficient of $v o c$ is positive and significant, indicating higher initial earnings for vocationally educated. At the same time, the interaction of $v o c$ with 
experience is significantly negative supporting a catching-up process of the generally educated over time. For the Netherlands, the respective coefficients tell a similar story, however, at a significance level of 5 per cent. For the United Kingdom, initial earnings differences between the two groups of employees are not significant. The negative and significant coefficient of the interaction-term $v o c^{*} \exp$, however, indicates a faster earnings growth of generally educated.

The graphical display deducted from the regressions (shown in Figures A.1 to A.3 in the appendix) is very similar to Figure 1 with Variant 2 representing the earnings profile for the generally educated group. Note that Figures A.1 to A.3 as well as all subsequent figures have been standardized to make a comparison of the magnitude of the differences and the progression of the curves easier.

Since the purpose of the pooled OLS models is to gain a first impression of the direction and size of the relationships, we at this stage refrain from discussion results from models containing a larger set of control variables, such as firm-size, job-type and industry of the firm. The results of such a model are, however, displayed in the separate appendix on robustness analysis (see B.1 in the appendix).

\subsection{Mixed-Effects Linear Regression Model}

The estimates presented above do not account for the fact that most individuals are observed for more than one time-period. Consequently, the observations in the pooled data-set are not necessarily independent from each other. Observations of the same individual are likely to be correlated, which could be partly due to between-person heterogeneity in the intercept (i.e. initial earnings) and partly due to the slopes of covariates (Rabe-Hesketh and Skrondal 2008). Further, the two groups might still differ not only in their observable characteristics, but also with respect to unobservable factors, like social background, motivation, interest or ability. The unobserved heterogeneity may play a role for both the decision to follow a vocational or general educational track and the subsequent earnings profile. As pointed out in the previous section, one component of our strategy 
to handle these potential selection problems is the narrowing down of the sample groups to employees that have achieved graduation at the uppersecondary level. Those employees whose highest educational attainment is at the lower-secondary or primary level are removed from the sample. Also, employees who have achieved a tertiary degree are not represented in the respective data sets 6 . We thus argue that the two groups of employees remaining in the sample are likely to be very similar concerning their unobservable characteristics.

We further develop a Mixed-Effects Linear Regression Model that takes into account the differences in the intercept and slope of the experience-earnings curve for vocationally and generally trained.

Building on equation 1 we start by describing a random-intercept model with the random intercept $\theta_{1 j}$ and the residual $\epsilon_{i j}$ being the permanent and the transitory error component of the model (Rabe-Hesketh and Skrondal 2008)7.

$$
y_{i j}=\beta_{1}+\beta_{2} \exp _{i j}+\beta_{3} \exp _{i j}^{2}+\beta_{4} X_{i}+\theta_{1 j}+\epsilon_{i j}
$$

The random intercept $\theta_{i}$ and $\epsilon_{i j}$ are both assumed to be normally distributed with a mean of zero, independent of each other, with $\theta_{i}$ independent across persons and $\epsilon_{i j}$ independent across persons and observations. While the model above allows for employee-specific intercepts, we can also model our assumption that earnings of different employees have different slopes over time by adding a random coefficient of labor market experience $\theta_{2 j} * e x p_{i j}$. The model now has the form

$$
y_{i j}=\beta_{1}+\beta_{2} \exp _{i j}+\beta_{3} \exp _{i j}^{2}+\beta_{4} X_{i}+\theta_{1 j}+\theta_{2 j} * \exp _{i j}+\epsilon_{i j}
$$

\footnotetext{
${ }^{6}$ However, it can not be ruled out that a share of employees with a highest educational degree at the upper-secondary level leaves the labor market to obtain a tertiary degree.

${ }^{7}$ In a "fixed-effects" approach $\theta_{1 j}$ is eliminated entirely from the model, which removes all time-invariant unobservable heterogeneity from the model. However, at the same time, the impact of observable time-invariant variables on the dependent variable cannot be estimated directly either. (Greene, 2008) discusses advantages and problems involved when choosing mixed linear models in the context of wage regressions.
} 
Table 1: Mixed-Effects Linear Regression Model

\begin{tabular}{|c|c|c|c|}
\hline Variable & Germany & Netherlands & United Kingdom \\
\hline & & hourly wage) & \\
\hline \multirow[t]{2}{*}{ Experience } & $0.0400^{* * *}$ & $0.0386^{* * *}$ & $0.0514^{* * *}$ \\
\hline & $(0.004)$ & $(0.006)$ & $(0.001)$ \\
\hline \multirow[t]{2}{*}{ Experience2 } & $-0.0007^{* * *}$ & $-0.0006^{* * *}$ & $-0.0010^{* * *}$ \\
\hline & $(0.000)$ & $(0.000)$ & $(0.000)$ \\
\hline \multirow[t]{2}{*}{ Vocational Education } & $0.0991^{* * *}$ & 0.0462 & $0.0470^{*}$ \\
\hline & $(0.020)$ & $(0.064)$ & $(0.020)$ \\
\hline \multirow[t]{2}{*}{ Voc*Experience } & $-0.0181^{* * *}$ & -0.0066 & $-0.0103^{* * *}$ \\
\hline & $(0.004)$ & $(0.007)$ & $(0.002)$ \\
\hline \multirow[t]{2}{*}{ Voc*Experience2 } & $0.0004^{* *}$ & 0.0001 & $0.0003^{* * *}$ \\
\hline & $(0.000)$ & $(0.000)$ & $(0.000)$ \\
\hline \multirow[t]{2}{*}{ Constant } & $2.1623^{* * *}$ & $1.8281^{* * *}$ & $1.3990^{* * *}$ \\
\hline & $(0.019)$ & $(0.054)$ & $(0.013)$ \\
\hline Observations & 72451 & 2500 & 39767 \\
\hline
\end{tabular}

To assess, whether there are systematic differences between vocationally and generally educated employees we add a dummy variable voc to the fixed part of the model. Further, to trace the differences between vocationally and generally educated over the dimension of experience, we add the cross-level interaction term voc ${ }^{*}$ experience. The finally estimated model yields

$$
\begin{aligned}
& y_{i j}=\beta_{1}+\beta_{2} \exp _{i j}+\beta_{3} \exp _{i j}^{2}+\beta_{4} X+\beta_{5} v o c_{i}+\beta_{6} v o c_{i} * \exp _{i j} \\
& +\beta_{7} v o c_{i} * \exp 2_{i j}+\theta_{1 j}+\theta_{2 j} * \exp _{i j}+\epsilon_{i j}
\end{aligned}
$$

Estimation results shown in Table 1 generally support those obtained on the basis of pooled OLS-regressions. With respect to the coefficient of interest indicating the difference in initial earnings (Vocational Education), it remains positive and significant in the case of Germany. However, for the United Kingdom the coefficient is now significant at the 5 per cent level whereas for the Netherlands it turns insignificant. 
Further, the negative and significant coefficient on the interaction between Vocational Education and Experience are significantly negative in Germany and the United Kingdom, supporting the notion that the slope of the experience - earnings profile is less steep for the vocationally educated. Again, for the Netherlands, the respective coefficient changes compared to simple pooled OLS estimate and turns insignificant.

Figure 2 for Germany, however, contains another message: Because the two curves intersect at an experience of about six years and the earnings curve of generally educated remains steeper than the one of vocationally educated, generally educated employees reach a notably higher level of productivity than vocationally educated. However, very late in the labor market career the two curves intersect again, when the earnings curve of generally educated comes down faster than for vocationally educated.

Figure 2: Mixed-Effects Linear Regression Model

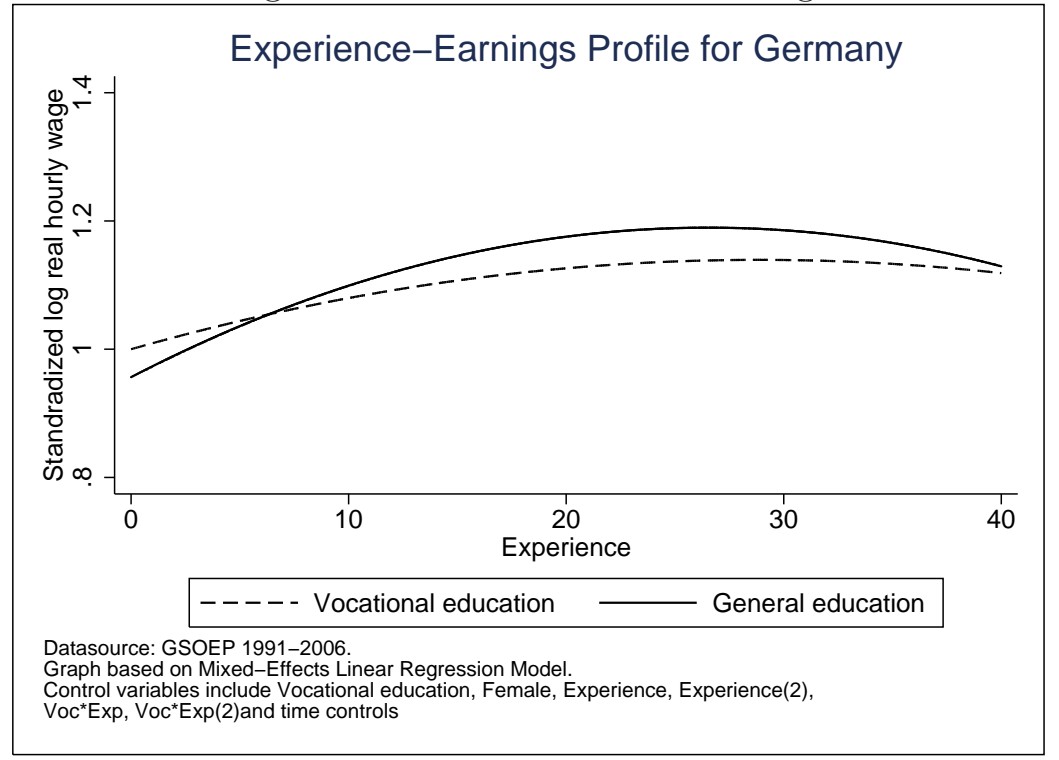

A similar result is obtained from the analysis for the United Kingdom, since the coefficients go in the same direction. Further, Figure 3 indicates that the initial earnings and slopes of the two curves are much closer together than in the German case. Again, the two curves intersect at an experience 
Figure 3: Mixed-Effects Linear Regression Model

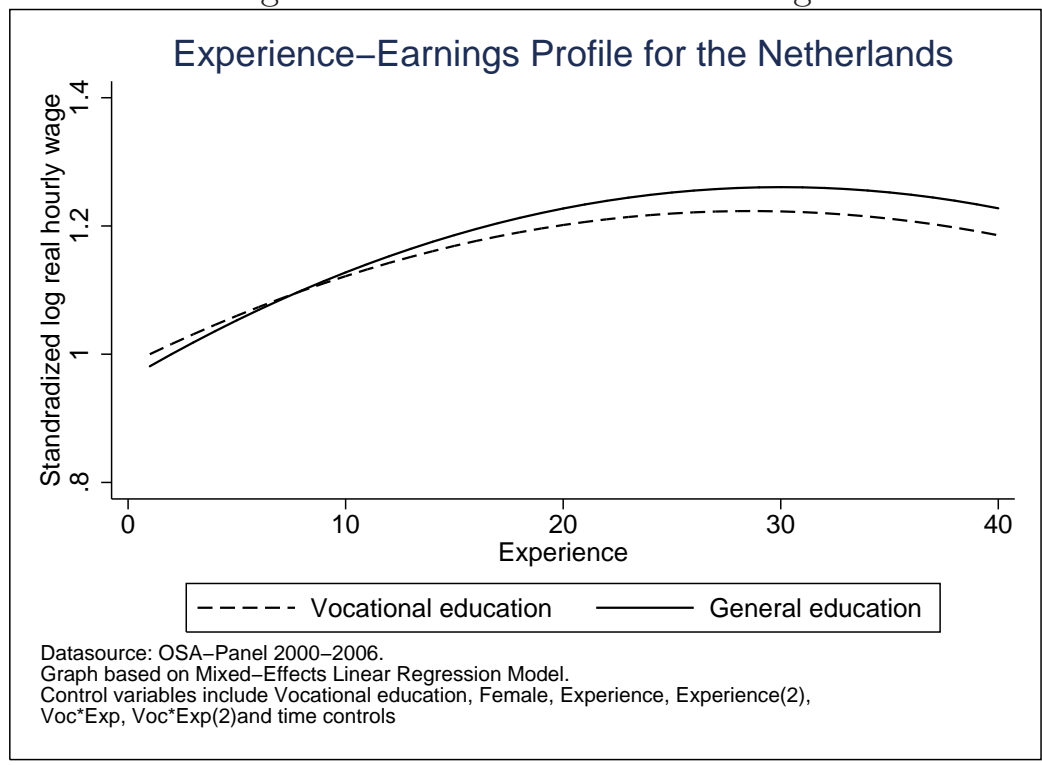

Figure 4: Mixed-Effects Linear Regression Model

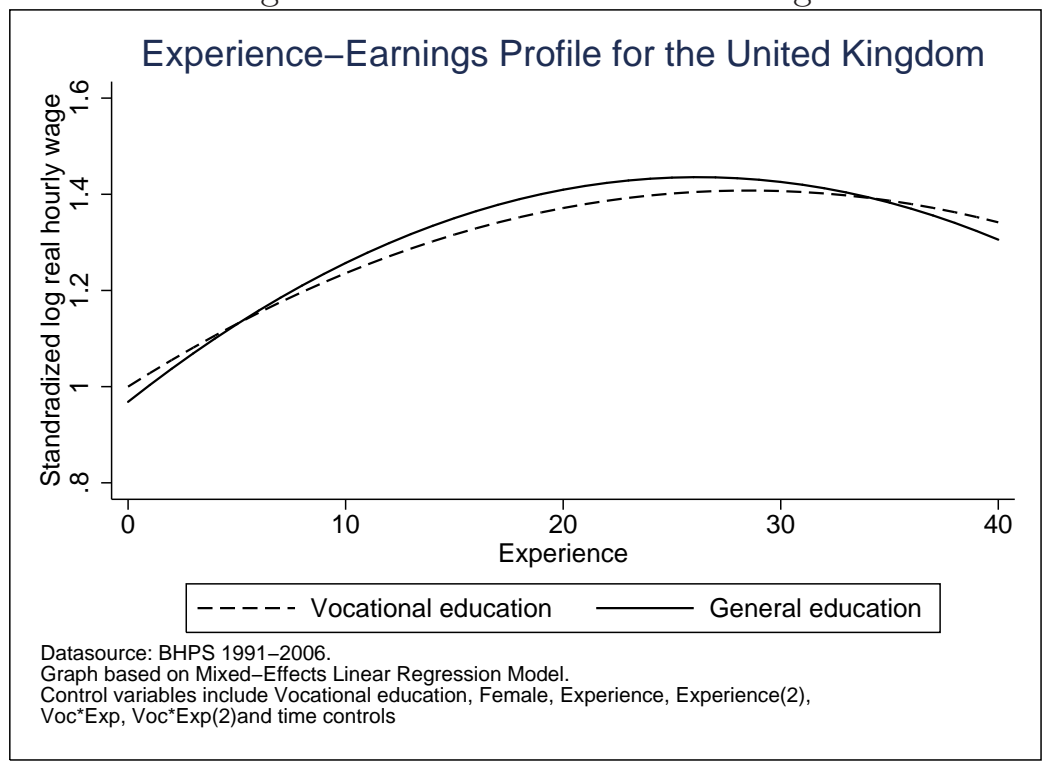


of about six years and intersect again late in the labor market career of the respective employees. Results for the Netherlands differ to the extent that the graphical display in Figure 4 is very close to the one obtained by estimating pooled OLS-regressions, however the differences between the two groups of employees are statistically not robust.

A number of robustness checks are performed to examine, whether the results hold under different conditions. First, we estimate spline-regressions on the pooled OLS (see Table B.2). The effect of vocational training remains significant for Germany but and, similar to th OLS-baseline model, are insignificant for the United Kingdom. Further, we estimated the Mixed Effects Linear Regression model for the subgroup of employees with less than 20 years of experience (see Table B.3). Again, for Germany the respective coefficients remained significant, whereas the coefficients for the United Kingdom turn out to be insignificant. The same result was obtained when including cohort dummies (not shown). Thus, results for Germany are extremely robust while those for the United Kingdom seem sensitive to variations in the estimation method and model. On the whole, the results for the Netherlands remained insignificant for all alternative specifications and estimation methods.

To further investigate on the ability problem discussed above, we followed an alternative approach, for which we construct an additional variable Cohort* vocshare representing the share of vocationally educated among employees with an upper-secondary qualification in a cohort (i.e. the variable is constant for all employees belonging to the cohort). The results of the corresponding mixed effects models and further explanations are given in in the appendix (Table B.4 and below). Although being highly significant in Germany and the Netherlands, the inclusion of this control variable does not fundamentally change the results presented in this section.

\section{Summary and Conclusions}

In this paper, we have analyzed experience-earnings profiles of differently educated employees. We showed that those employees having undergone 
vocational education have higher earnings at the beginning of their labor market career than those having received general education. The underlying hypothesis is that vocational specialization paired with working practice improves the fit between job requirements and individual skills and therefore leads to a better initial match on the labor market compared to those without vocational training. With increasing work experience, however, generally educated catch up in terms of productivity and earnings due to informal and formal on-the-job training. The optimal productivity (and earnings) level then may or may not differ between the two groups of employees. The countries for which the analysis was done have been chosen because of the differences in their education systems and labor market institutions. Germany and the Netherlands, on the one hand, are countries with an elaborate vocational education and training system and occupationally organized labor markets. The United Kingdom, on the other hand, is known for "producing" mainly general skills and for featuring internal labor markets, in which experience and tenure "sort" individuals to their labor market position.

Using panel data for all three countries, a first set of simple pooled OLSregressions supported the expectation of higher initial earnings for vocationally educated employees in the three countries. At around six years of experience earnings curves intersect with the curve of generally educated. From there on, the experience-earning curve of generally educated exceeds that of the vocationally educated. Results on the basis of a Mixed-Effects Linear Regression Model showed that this observation is statistically significant for Germany and the United Kingdom. For the Netherlands, however, the results reveal that initial earnings of the two groups of employees do not differ significantly. This is also the case concerning differences in the slopes of the respective experience-earnings curves. Despite narrowing down the comparison groups to employees with a highest educational attainment at the upper-secondary level and despite performing a number of robustness checks, we cannot claim to fully control for selectivity into both education and labor market. We thus need to take into account that the results obtained in this paper could be biased, most likely in favor of the generally 
educated.

Having a possible selection bias in mind, we interpret these results in the following way. Considering that in Germany the group of vocationally educated to a large extent consists of former apprentices with high shares of working-practice, it is no surprise to find that the match between skills and job requirements is better than for generally educated employees. The earnings differential in favor of the vocationally educated is significant in this country. This result also seems plausible considering that an intense cooperation exists between unions, employer organizations and state authorities in defining the contents of vocational education and training. Employers have good knowledge of the skills and competencies acquired by vocationally educated employees and tailor the responsibilities and requirements of jobs to be filled accordingly. In addition, around two thirds of former apprentices are retained in the training firm, indicating a smooth transition from the status as trainee to a status of employee. In the Netherlands the share of upper-secondary graduates with apprenticeship training is somewhat lower and consequently the (initial) advantage of vocationally educated is less pronounced. Further, Dutch law requires all students enrolled in vocational programs to be educated in a way that allows for a smooth transition to tertiary academic education. Although in practice the number of those entering tertiary level after having obtained a vocational qualification is rather small (although larger than in Germany), institutions and firms are likely to focus much more on general knowledge and skills than in Germany. Although the respective coefficients are weakly significant for the United Kingdom, robustness checks show that the underlying relationship is not stable in this country. Again, this seems plausible considering that in the United Kingdom vocational tracks are usually taught in full-time schools and colleges and thus contain relatively small shares of practical training. Another result from the above analysis is that generally educated reach higher earnings-levels than vocationally trained after a certain period in the labor market. One reason for this could be that general education focuses relatively more on general knowledge and problem solving skills, which could lead to higher learning abilities throughout working life. However, further 
research is necessary to confirm this hypothesis since continuing vocational training and its effects on productivity and wages were beyond the scope of this paper. The present work also calls for a further differentiation of different types of vocational education and training on the upper-secondary level to obtain clarity on the impact of the share of practical training on earnings. Our results suggest, however, that the way of organizing vocational education and training may have an impact on the differences between earnings-profiles of vocationally generally educated employees. 


\section{References}

Acemoglu, Daron and Joern-Steffen Pischke (1998). Why Do Firms Train? Theory and Evidence. Quarterly Journal of Economics 113(1), 79-119.

Acemoglu, Daron and Joern-Steffen Pischke (1999). Beyond Becker: Training in Imperfect Labour Markets. Economic Journal 109, F112-F142.

Baethge, Martin, Heike Solga, and Martin Wieck (2006). Berufsbildung im Umbruch. Signale eines überfälligen Aufbruchs. Gutachten zur beruflichen Bildung in Deutschland. Technical report, Friederich-Ebert-Stiftung.

Becker, Gary S. (1964). Human Capital: A Theoretical and Empirical Analysis with Special Reference to Education. New York; London: Columbia University Press.

Booth, Alison L. and Gylfi Zoega (2004). Is Wage Compression a Necessary Condition for Firm-Financed General Training? Oxford Economic Papers 56(1), 88-97.

Bowman, Mary Jean (1993). The Economics of Education in a World of Change. In E.P.Hoffman (Ed.), Essays on the Economics of Education, pp. 163-175. Upjohn Institute for Employment Research, Michigan.

Brauns, Hildegard and Susanne Steinmann (1999). Educational Reform in France, West-Germany and the United Kingdom: Updating the CASMIN Educational Classification. ZUMA-Nachrichten 44, 7Ü44.

Brunello, Giorgio (2002). Is Training more Frequent when Wage Compression is Higher? Evidence from 11 European Countries.

CEDEFOP (2008). Country Report - Thematic Overview: United Kingdom. Technical report, CEDEFOP.

Dearden, Lorraine, Howard Reed, and John Van Reenen (2006). The Impact of Training on Productivity and Wages: Evidence from British Panel Data. Oxford Bulletin of Economics and Statistics 68(4), 397-421. 
Gangl, Markus (2000). European Perspectives on Labour Market Entry : A Matter of Institutional Linkages between Training Systems and Labour Markets? MZES Arbeitspapiere (24).

Gangl, Markus (2002). Changing Labour Markets and Early Career Outcomes : Labour Market Entry in Europe over the Past Decade. Work Employment Society 16(26), 67-90.

Goldin, Claudia (2001). The Human Capital Century and American Leadership: Virtues of the Past. NBER-Working Papers No. 8239.

Greene, William H. (2008). Econometric Analysis (5 ed.). N.J.: Prentice Hall.

Grossbard, Shoshana, ed. (2006). Jacob Mincer: A Pioneer of Modern Labor Economics. New York:

Gustman, Alan and Thomas Steinmeier (1982). Labor Markets and Evaluations of Vocational Training Programs in the Public High Schools: Toward a Framework for Analysis. Southern Economic Journal 49(1), 185-200.

Hartog, Joop (1992). Capabilities, Allocation and Earnings. Kluwer Academic Publishers.

Heidenreich, Martin (1998). Die duale Berufsausbildung zwischen industrieller Prägung und wissensgesellschaftlicher Herausforderung. Zeitschrift für Soziologie 27/5, 321-341.

Hotchkiss, Lawrence (1993). Effects of Training, Occupation, and TrainingOccupation Match on Wage. The Journal of Human Resources 28(3), 482-496.

Jovanovic, Boyan (1979). Job Matching and the Theory of Turnover. Journal of Political Economy 87(5), pp. 972 - 990.

Marsden, David and Paul Ryan (1986). Where Do Young Workers Work? Youth Employment by Industry in Various European Economies. British Journal of Industrial Relations 24(1), 83-102. 
Marsden, David and Paul Ryan (1991). The structuring of youth pay and employment in six industrial economies. In P.Ryan, P.Garonna, and R.C.Edwards (Eds.), The problem of youth: the regulation of youth employment and training in advanced economies. Palgrave Macmillan.

Meer, Jonathan (2007). Evidence on the returns to secondary vocational education. Economics of Education Review 26, 559-573.

Meyer, Robert H. (1982). Job Training in the Schools. In RobertTaylor, HowardRosen, and FrankPratzner (Eds.), Job Training for Youth, pp. 307-44. The National Center for Research in Vocational Education, Ohio State University.

Mincer, Jacob (1974). Schooling, experience and earnings. National Bureau of Economic Research.

Mincer, Jakob (1958). Investment in Human Capital and Personal Income Distribution. Journal of Political Economy 66(4), 281-302.

Neuman, Shoshana and Adrian Ziderman (1991). Vocational Schooling, Occupational Matching and Labor Market Earnings in Israel. The Journal of Human Resources 26(2), 256-281.

Neuman, Shoshana and Adrian Ziderman (1999). Vocational Education in Israel: Wage Effects of the VocEd-Occupation Match. The Journal of Human Resources 34(2), 407-420.

OECD (2008). Education at a Glance. OECD, Paris.

Pischke, Jorn-Steffen, Josef Fersterer, and Rudolf Winter-Ebmer (2007). The returns to apprenticeship training in Austria: evidence from failed firms. Working Paper 13344, National bureau of economic research, Massachusetts, USA.

Rabe-Hesketh, Sophia and Anders Skrondal (2008). Multilevel and Longitudinal Modeling Using Stata (Second Edition ed.). Stata Press.

Thurow, Lester C. (1975). Generating Inequality. Basic Books, New York. 
van Eijs, Patrick and Hans Heijke (2000). Mismatch between Occupation and Education and the Costs and Benefits of Job-related Training. In H.Heijke and J.Muysken (Eds.), Education and Training in a KnowledgeBased Economy, pp. 159-189. Macmillan Press.

Willis, Robert J. and Sherwin Rosen (1979). Education and Self-Selection. Journal of Political Economy 87(5), 7-36. 


\section{A Descriptive Statistics and Pooled OLS Regres- sion Results}

Table A.1: Descriptive Statistics - Germany

\begin{tabular}{lcc} 
& General Education & Vocational Education \\
\hline & Mean & Mean \\
\hline Individual characteristics & 30.896 & 40.255 \\
Age & 0.455 & 0.429 \\
Female & 0.545 & 0.571 \\
Male & 0.888 & 0.918 \\
National & 0.112 & 0.082 \\
Foreign & & \\
Employment characteristics & 12.980 & 13.068 \\
Hourly wage & 7.224 & 18.177 \\
Experience & 0.537 & 0.806 \\
Full-time & 0.463 & 0.194 \\
Part-time & & \\
Firm characteristics & 0.345 & 0.302 \\
Firm size < 20 & 0.252 & 0.281 \\
Firm size 20-200 & 0.190 & 0.213 \\
Firm size 200-2000 & 0.213 & 0.203 \\
Firm size > 2000 & & \\
Industry (NACE) & 0.007 & 0.020 \\
Agriculture & 0.001 & 0.006 \\
Mining and quarrying & 0.163 & 0.295 \\
Manufacturing & 0.006 & 0.013 \\
Electricity, gas and water supply & 0.041 & 0.097 \\
Construction & 0.148 & 0.157 \\
Wholesale and retail trade & 0.049 & 0.021 \\
Hotels and restaurants & 0.062 & 0.063 \\
Transport and communication & 0.048 & 0.039 \\
Financial intermediation & 0.135 & 0.046 \\
Real estate & & \\
\hline
\end{tabular}

continued on next page... 
...continued from previous page

\begin{tabular}{lcc} 
& General Education & Vocational Education \\
\hline & Mean & Mean \\
\hline continuation Industry (NACE) & & \\
Public administration & 0.063 & 0.078 \\
Education & 0.090 & 0.022 \\
Health & 0.102 & 0.097 \\
Other services & 0.083 & 0.041 \\
Activities of households & 0.002 & 0.005 \\
Extra-territorial organizations & 0.002 & 0.001 \\
Job skill level (ISCO) & & \\
Senior officials and managers & 0.056 & 0.045 \\
Professionals & 0.207 & 0.028 \\
Technicians & 0.234 & 0.221 \\
Clerks & 0.155 & 0.143 \\
Service workers & 0.143 & 0.128 \\
Skilled agricultural workers & 0.001 & 0.015 \\
Craft and related trades workers & 0.059 & 0.246 \\
Plant and machine operators & 0.043 & 0.103 \\
Elementary occupations & 0.101 & 0.071 \\
\hline Observations & 2385 & 70066 \\
\hline Source: GSOEP 1991-2006 & & \\
& &
\end{tabular}


Table A.2: Descriptive Statistics - Netherlands

\begin{tabular}{lcc} 
& General Education & Vocational Education \\
\hline & Mean & Mean \\
\hline Individual characteristics & 38.751 & \\
Age & 0.560 & 39.392 \\
Female & 0.440 & 0.460 \\
Male & 0.958 & 0.540 \\
Dutch & 0.042 & 0.971 \\
Foreign & & 0.029 \\
Employment characteristics & 10.581 & \\
Hourly wage & 17.403 & 10.272 \\
Experience & 0.610 & 18.786 \\
Full-time & 0.390 & 0.690 \\
Part-time & & 0.310 \\
Firm characteristics & 0.290 & \\
Firm size < 25 & 0.253 & 0.287 \\
Firm size 25-100 & 0.345 & 0.246 \\
Firm size 100-1000 & 0.109 & 0.370 \\
Firm size > 1000 & & 0.094 \\
Industry (SBI) & 0.016 & \\
Agriculture & 0.082 & 0.014 \\
Industry & 0.016 & 0.145 \\
Building and Construction & 0.174 & 0.064 \\
Wholesale and retail trade & 0.114 & 0.186 \\
Transport and communication & 0.208 & 0.076 \\
Material services & 0.042 & 0.121 \\
Other services & 0.147 & 0.027 \\
Public administration & 0.040 & 0.096 \\
Education & 0.160 & 0.025 \\
Health & & 0.247 \\
Job skill level (SBC92) & 0.036 & \\
Elementary & 0.285 & 0.040 \\
Low & 0.436 & 0.218 \\
Middle & 0.216 & 0.562 \\
High & 0.027 & 0.159 \\
Scientific & 754 & 1746 \\
\hline Observations & &
\end{tabular}


Table A.3: Descriptive Statistics - United Kingdom

\begin{tabular}{lcc} 
& General Education & Vocational Education \\
\hline & Mean & Mean \\
\hline Individual characteristics & 34.177 & 37.550 \\
Age & 0.509 & 0.500 \\
Female & 0.491 & 0.500 \\
Male & 0.996 & 0.995 \\
National & 0.004 & 0.005 \\
Foreign & & \\
Employment characteristics & 10.948 & 11.099 \\
Hourly wage & 16.177 & 19.550 \\
Experience & 3.896 & 4.578 \\
Tenure & 0.848 & 0.840 \\
Full-time & 0.152 & 0.160 \\
Part-time & & \\
Firm characteristics & 0.345 & 0.333 \\
Firm size <20 & 0.248 & 0.242 \\
Firm size 20-200 & 0.289 & 0.304 \\
Firm size 200-2000 & 0.108 & 0.108 \\
Firm size $>$ 2000 & & \\
Industry (NACE) & 0.008 & 0.008 \\
Agriculture & 0.000 & 0.007 \\
Mining and quarrying & 0.005 & 0.184 \\
Manufacturing & 0.020 & 0.023 \\
Electricity, gas and water supply & 0.058 & 0.060 \\
Construction & 0.083 & 0.082 \\
Wholesale and retail trade & 0.018 & 0.014 \\
Hotels and restaurants & 0.090 & 0.075 \\
Transport and communication & 0.083 & 0.070 \\
Financial intermediation & 0.053 & 0.043 \\
Real estate & 0.070 & 0.062 \\
Public administration & 0.131 & 0.091 \\
Education & 0.047 & 0.060 \\
Health & 0.117 & 0.099 \\
Other services & 0.086 & 0.114 \\
Activities of households & 0.006 & 0.007 \\
Extra-territorial organizations & & \\
\hline
\end{tabular}

continued on next page... 
...continued from previous page

\begin{tabular}{lcc} 
& General Education & Vocational Education \\
\hline Job skill level (ISCO) & Mean & Mean \\
Senior officials and managers & 0.154 & \\
Professionals & 0.070 & 0.132 \\
Technicians & 0.146 & 0.051 \\
Clerks & 0.238 & 0.170 \\
Service workers & 0.174 & 0.221 \\
Skilled agricultural workers & 0.007 & 0.140 \\
Craft and related trades workers & 0.075 & 0.007 \\
Plant and machine operators & 0.080 & 0.160 \\
Elementary occupations & 0.056 & 0.076 \\
\hline Observations & 19059 & 0.043 \\
\hline So & & 20711 \\
\hline
\end{tabular}

Source: BHPS 1991-2006 
Table A.4: OLS Regression - baseline model

\begin{tabular}{lrrr}
\hline Variable & Germany & Netherlands & United Kingdom \\
\hline & & $\log ($ hourly wage $)$ & \\
Experience & $0.0454^{* * *}$ & $0.0472^{* * *}$ & $0.0491^{* * *}$ \\
& $(0.003)$ & $(0.005)$ & $(0.001)$ \\
Experience2 & $-0.0007^{* * *}$ & $-0.0008^{* * *}$ & $-0.0009^{* * *}$ \\
& $(0.000)$ & $(0.000)$ & $(0.000)$ \\
Vocational Education & $0.1285^{* * *}$ & $0.1030^{*}$ & 0.0309 \\
& $(0.016)$ & $(0.049)$ & $(0.016)$ \\
Voc*Experience & $-0.0246^{* * *}$ & $-0.0133^{*}$ & $-0.0066^{* * *}$ \\
& $(0.003)$ & $(0.006)$ & $(0.002)$ \\
Voc*Experience2 & $0.0003^{* *}$ & 0.0003 & $0.0001^{* *}$ \\
& $(0.000)$ & $(0.000)$ & $(0.000)$ \\
Constant & $1.7929^{* * *}$ & $1.6910^{* * *}$ & $1.5405^{* * *}$ \\
\hline Observations & 72451 & 2500 & 39767 \\
\hline
\end{tabular}

Standard errors in parentheses.

Models also include a control for female employees and year dummies (not shown).

${ }^{*} p<0.05,{ }^{* *} p<0.01,{ }^{* * *} p<0.001$

Figure A.1: OLS-Regression - baseline model

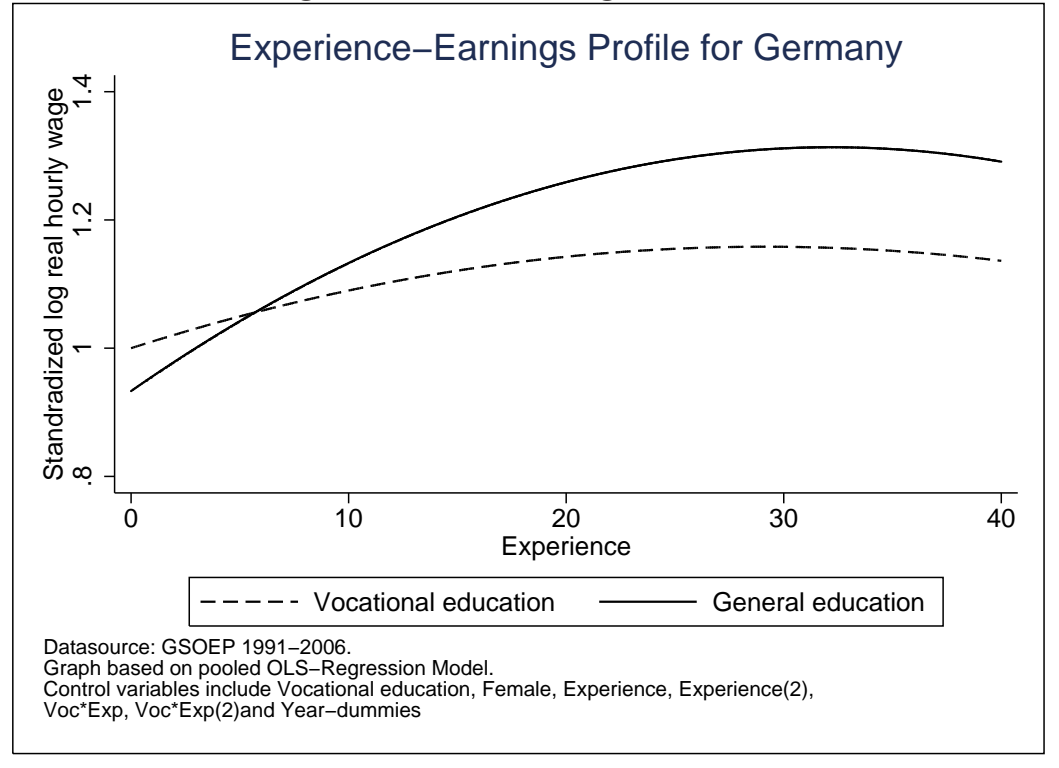


Figure A.2: OLS-Regression - baseline model

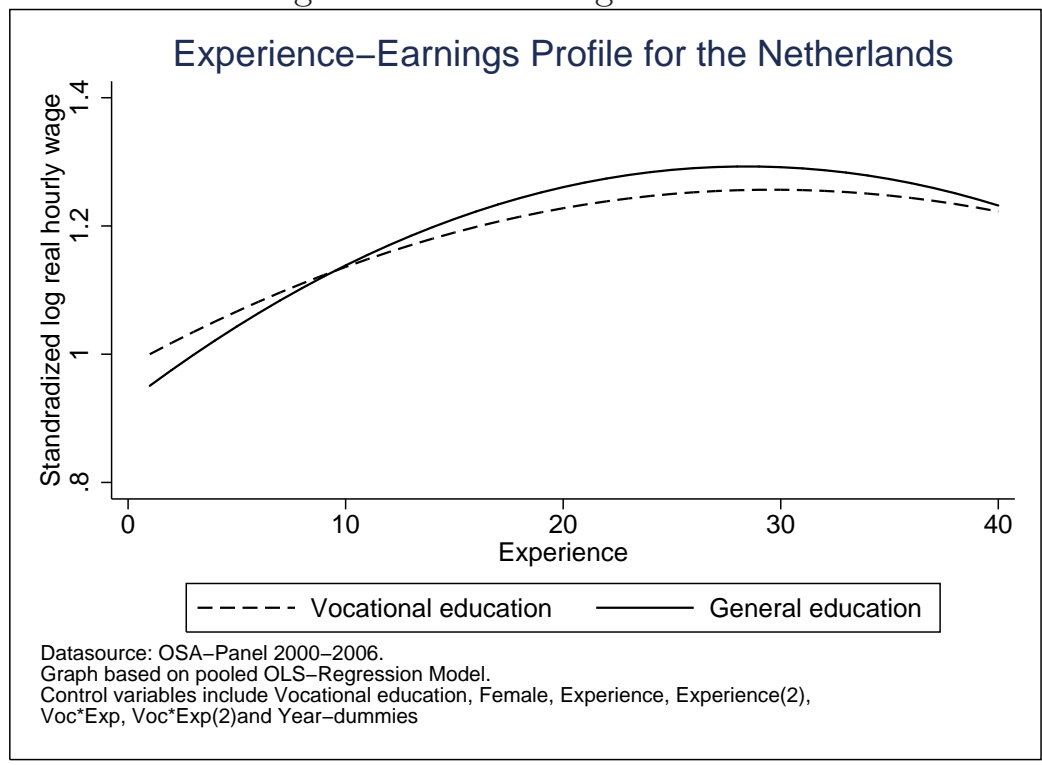

Figure A.3: OLS-Regression - baseline model

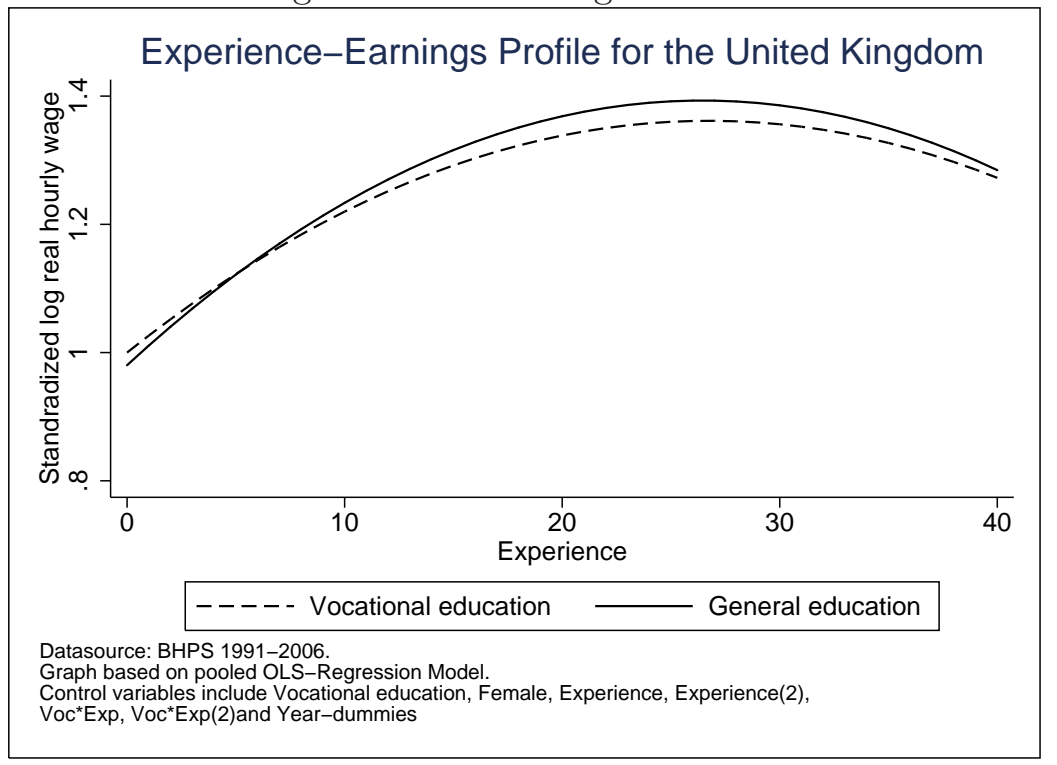




\section{B Robustness analysis and alternative estimates}

\section{B.1 Robustness analysis}

Table B.1: Pooled OLS-regressions with additional control variables

\begin{tabular}{|c|c|c|c|}
\hline Variable & Germany & Netherlands & United Kingdom \\
\hline \multicolumn{4}{|c|}{ Log(hourly wage) } \\
\hline \multirow[t]{2}{*}{ Experience } & $0.0431^{* * *}$ & $0.0410^{* * *}$ & $0.0359^{* * *}$ \\
\hline & $(0.003)$ & $(0.005)$ & $(0.001)$ \\
\hline \multirow[t]{2}{*}{ Experience2 } & $-0.0008^{* * *}$ & $-0.0007^{* * *}$ & $-0.0007^{* * *}$ \\
\hline & $(0.000)$ & $(0.000)$ & $(0.000)$ \\
\hline \multirow[t]{2}{*}{ Vocational Education } & $0.1741^{* * *}$ & 0.0891 & $0.0561^{* * *}$ \\
\hline & $(0.015)$ & $(0.048)$ & $(0.015)$ \\
\hline \multirow[t]{2}{*}{ Voc*Experience } & $-0.0241^{* * *}$ & -0.0101 & $-0.0061^{* * *}$ \\
\hline & $(0.003)$ & $(0.005)$ & $(0.002)$ \\
\hline \multirow[t]{2}{*}{ Voc*Experience2 } & $0.0004^{* * *}$ & 0.0002 & $0.0001^{*}$ \\
\hline & $(0.000)$ & $(0.000)$ & $(0.000)$ \\
\hline \multirow[t]{2}{*}{ Constant } & $2.2727^{* * *}$ & $1.6043^{* * *}$ & $1.9206^{* * *}$ \\
\hline & $(0.025)$ & $(0.067)$ & $(0.036)$ \\
\hline Observations & 72451 & 2500 & 39767 \\
\hline \multicolumn{4}{|c|}{ Standard errors in parentheses } \\
\hline \multicolumn{4}{|c|}{$\begin{array}{l}\text { Models also include controls for female employees, nationality, part-time work, firm-size, industry, } \\
\text { occupation and year-dummies. } \\
{ }^{*} p<0.05,{ }^{* *} p<0.01,{ }^{* * *} p<0.001\end{array}$} \\
\hline
\end{tabular}


Table B.2: Spline-regressions with 5 splines for experience

\begin{tabular}{lrrr}
\hline Variable & Germany & Netherlands & United Kingdom \\
\hline \multirow{2}{*}{ Experience1 } & $0.0433^{* * *}$ & $0.0487^{* * *}$ & $0.0518^{* * *}$ \\
Experience2 & $(0.002)$ & $(0.005)$ & $(0.002)$ \\
& $0.0182^{* * *}$ & $0.0172^{* * *}$ & $0.0214^{* * *}$ \\
Experience3 & $(0.001)$ & $(0.004)$ & $(0.001)$ \\
& $0.0168^{* * *}$ & 0.0020 & $0.0030^{*}$ \\
Experience4 & $(0.001)$ & $(0.003)$ & $(0.001)$ \\
& $0.0113^{* * *}$ & $0.0110^{*}$ & $0.0031^{*}$ \\
Experience5 & $(0.002)$ & $(0.004)$ & $(0.002)$ \\
Vocational education & $0.0124^{* * *}$ & -0.0021 & $-0.0064^{* *}$ \\
& $(0.002)$ & $(0.007)$ & $(0.002)$ \\
Voc*Experience & $0.0324^{*}$ & 0.0300 & -0.0147 \\
& $(0.013)$ & $(0.030)$ & $(0.010)$ \\
Constant & $-0.0110^{* * *}$ & -0.0028 & $-0.0011^{*}$ \\
& $(0.001)$ & $(0.001)$ & $(0.000)$ \\
\hline Observations & $1.8953^{* * *}$ & $1.5612^{* * *}$ & $1.5186^{* * *}$ \\
\hline Stantar & $(0.015)$ & $(0.067)$ & $(0.038)$ \\
\hline
\end{tabular}

Standard errors in parentheses.

${ }^{*} p<0.05,{ }^{* *} p<0.01,{ }^{* * *} p<0.001$ 
Table B.3: Mixed-Effects Linear Regression Model - Employees $<20$ years of experience

\begin{tabular}{lrrr}
\hline Variable & Germany & Netherlands & United Kingdom \\
\hline & & Log(hourly wage) & \\
Experience & $0.0483^{* * *}$ & $0.0812^{* * *}$ & $0.0634^{* * *}$ \\
& $(0.006)$ & $(0.013)$ & $(0.003)$ \\
Experience2 & $-0.0013^{* * *}$ & $-0.0025^{* * *}$ & $-0.0015^{* * *}$ \\
& $(0.000)$ & $(0.001)$ & $(0.000)$ \\
Vocational Education & $0.0621^{* *}$ & 0.1166 & 0.0006 \\
& $(0.022)$ & $(0.096)$ & $(0.025)$ \\
Voc*Experience & $-0.0136^{*}$ & -0.0303 & -0.0064 \\
& $(0.006)$ & $(0.016)$ & $(0.005)$ \\
Voc*Experience & 0.0004 & $0.0013^{*}$ & 0.0003 \\
& $(0.000)$ & $(0.001)$ & $(0.000)$ \\
Constant & $2.1469^{* * *}$ & $1.6270^{* * *}$ & $1.3754^{* * *}$ \\
& $(0.021)$ & $(0.076)$ & $(0.015)$ \\
\hline Observations & 43567 & 1516 & 23620 \\
\hline
\end{tabular}

Standard errors in parentheses.

Models also include a control for female employees and time controls (not shown).

${ }^{*} p<0.05,{ }^{* *} p<0.01,{ }^{* * *} p<0.001$ 


\section{B.2 Alternative estimates including the additional control variable Cohort $*$ vocshare}

Ad Table B.3. The variable Cohort ${ }^{*}$ vocshare has been introduced as an additional variable to control for ability differences between individuals of different cohorts who do not continue to higher education but end up in vocational education or general education. The basic assumptions are: (1) the ability structure of the population is constant between cohorts; (2) the required ability for following general education and continuing in higher education is generally higher than for vocational education; (3) a higher ability level is associated with a higher wage, ceteris paribus. It is to be expected now that if the share of vocationally educated and trained in a specific cohort is higher than in another, those additionally entering VET are more able than the average student already in VET because less individuals of the cohort will do general education and continue to higher education. The average ability of students in the cohort rises, which impacts positively on wages. Vice versa, a lower share of students in VET would mean that the more able students of the cohort have continued to higher education and consequently the average ability of students in VET is lower, leading to lower wages.

The result can be summarized as follows: In Germany and the Netherlands, the coefficient on Cohort*vocshare is large, positive and significant, supporting our assumptions made above. In the United Kingdom, on the other hand, the coefficient on Cohort $*$ vocshare is positive but not significant. Compared to the regression results excluding the variable on Cohort $*$ vocshare, the main variables of interest have changed with respect to their magnitude, but not with respect to their level of significance. This is especially the case for Germany and the Netherlands. For the United Kingdom, the magnitude of the coefficients of interest changes only marginally. 
Table B.4: Mixed-Effects Linear Regression Model - Alternative Estimates

\begin{tabular}{lrrr}
\hline Variable & Germany & Netherlands & United Kingdom \\
\hline & $0.0347^{* * *}$ & Log(hourly wage $)$ & $0.0509^{* * *}$ \\
Experience & $(0.004)$ & $(0.006)$ & $(0.002)$ \\
Experience & $-0.0007^{* * *}$ & $-0.0005^{* * *}$ & $-0.0010^{* * *}$ \\
& $(0.000)$ & $(0.000)$ & $(0.000)$ \\
Vocational Education & $0.0757^{* * *}$ & 0.0103 & $0.0421^{*}$ \\
& $(0.020)$ & $(0.064)$ & $(0.020)$ \\
Voc*Experience & $-0.0159^{* * *}$ & -0.0033 & $-0.0100^{* * *}$ \\
& $(0.004)$ & $(0.007)$ & $(0.002)$ \\
Voc*Experience 2 & $0.0003^{*}$ & 0.0000 & $0.0003^{* * *}$ \\
Cohort $*$ vocshare & $(0.000)$ & $(0.000)$ & $(0.000)$ \\
& $0.5868^{* * *}$ & $0.5013^{* * *}$ & 0.0313 \\
Constant & $(0.091)$ & $(0.146)$ & $(0.054)$ \\
& $1.6354^{* * *}$ & $1.5199^{* * *}$ & $1.3920^{* * *}$ \\
& $(0.083)$ & $(0.112)$ & $(0.024)$ \\
\hline Observations & 72451 & 2500 & 39767 \\
\hline \hline
\end{tabular}

Standard errors in parentheses.

Models also include a control for female employees and time controls (not shown).

${ }^{*} p<0.05,{ }^{* *} p<0.01,{ }^{* * *} p<0.001$ 